\section{Developmental Maturation of Susceptibility to Scrapie in Mice}

AGE at the time of injection has not been shown to influence the incubation period of peripherally injected scrapie in mice over 6 days old ${ }^{1}$, although a slight negative regression from birth to four months has been found for the intracerebral route $^{2}$. We report here, marked incubation period changes of three scrapie agents given intraperitioneally when the mice were injected neonatally instead of as adults.

Table 1 The Incubation Periods Shown by Weanling Mice after an Intraperitoneal Injection of Various Strains of Scrapie Agent

\begin{tabular}{ccccc}
\hline $\begin{array}{c}\text { Agent } \\
\text { (mouse- }\end{array}$ & $\begin{array}{c}\text { Inbred } \\
\text { mouse }\end{array}$ & $\begin{array}{c}\text { Dilution } \\
\text { of infected }\end{array}$ & \multicolumn{2}{c}{$\begin{array}{c}\text { Incubation periods } \pm \text { s.e. } \\
\text { (days) in weanlings* }\end{array}$} \\
passaged) & strain & brain & Females & Males \\
$22 A$ & VM & $10^{-2}$ & $319 \pm 6$ & $355 \pm 5$ \\
$79 A$ & VL & $10^{-2}$ & $205 \pm 1$ & $215 \pm 2$ \\
ME7 & C57BL & $10^{-1}$ & $225 \pm 4$ & $233 \pm 3$ \\
& & $10^{-2}$ & $249 \pm 2$ & $250 \pm 4$ \\
& & $10^{-3}$ & $278 \pm 6$ & $275 \pm 3$ \\
\hline
\end{tabular}

* Weaned at 21 days old.

The inocula were $10^{-1}, 10^{-2}$ or $10^{-3}$ supernates $(500 \mathrm{~g}$, $10 \mathrm{~min}$ ) of saline mouse-brain homogenates from terminal cases with ME7, 79A and 22A strains of scrapie $^{3-6}$. Each agent was injected $(0.02 \mathrm{ml}$.) intraperitoneally into $\mathrm{C} 57 \mathrm{BL}$, VL or VM mice, ranging in age from birth to 28 days. Any leakage of inoculum in 0 to 6 day old mice was minimized by inserting the fine needle ( $32 \mathrm{G}$ ) anterior to the xiphisternum, through a long subcutaneous track, and penetrating the peritoneum adjacent to the liver, which assisted as a non-return valve. The injection site was sealed immediately with 'Nobecutane' acrylic solution. Table 1 gives incubation periods ${ }^{4}$ for weanling mice with these agent/host strain combinations. Animals showing no clinical signs or histological lesions of scrapie, and which died or had to be killed over 550 days of age, were regarded as survivors. Depending on the particular agent/host combination, these survivors exceeded the mean incubation period for weanlings by more than 10 to 50 standard deviations.
Injection of very young mice frequently produced some survivors and a proportion of much longer or appreciably shorter incubation periods than those observed in weanling mice (Table 2). Cases following neonatal injection with ME7 agent tended to occur earlier with high titre inocula but later with low titre ones than in the weanling group, and survivors only occurred in the newborn group given the lowest titre. The proportion of survivors using $10^{-2}$ homogenates was higher with the $22 \mathrm{~A}$ and $79 \mathrm{~A}$ agents than with ME7. It must be emphasized that survivors do not occur in weanlings using these doses, either in these or in large numbers of other comparable experiments.

Several explanations for this phenomenon are relevant to the early pathogenesis of scrapie following peripheral inoculation. Neonatal mice probably lack some cell populations required for the initiation of pathogenesis. Hypotheses about the cause of the age-effect need to take account of the paradox that these data would give lower titre estimates using neonatal mice than using weanlings but with shorter incubation periods than weanlings at high doses. Two competing conditions may be present in the host, one favouring replication, the other destruction, of agent, and the outcome would depend on the balance of an individual's developmental state and the dose of agent.

The earliest replication of scrapie agent is known to take place in lymphoreticular tissue ${ }^{7}$, indicating this to be the relevant system which is maturing in mice during the first postnatal week. There are numerous cell types in this tissue whose immaturity is involved in neonatal immunological immaturity ${ }^{8,9}$ and age-dependent susceptibility to virus infections ${ }^{10,11}$. These age-dependent effects with scrapie are quite different from those with conventional viruses and, if due to lymphoreticular maturation, are unlikely to implicate either specific immune reactions or interferon production as these appear to play no part in the pathogenesis of scrapie $e^{12-16}$

The occurrence of survivors in mice given doses which would be lethal for all weanlings, raises the question of what happens to the agent in these individuals. There is no realistic possibility that leakage of inoculum can explain these results with the precautions we used, because even prolonged incubation periods would require the leakage of nearly all of it. The remarkable loss in effective titre, in conjunction with the

Table 2 The Distribution of Incubation Periods* of Three Scrapie Agents Injected i.p. in Mice of Different Ages

\begin{tabular}{|c|c|c|c|c|c|c|c|c|c|c|}
\hline \multirow{2}{*}{$\begin{array}{c}\text { Agent } \\
\text { (mouse- } \\
\text { passaged) }\end{array}$} & \multirow{2}{*}{$\begin{array}{l}\text { Inbred } \\
\text { mouse } \\
\text { strain }\end{array}$} & \multirow{2}{*}{$\begin{array}{l}\text { Dilution } \\
\text { of infected } \\
\text { brain }\end{array}$} & \multirow[b]{2}{*}{$\begin{array}{c}\text { Age } \\
\text { (days) }\end{array}$} & \multirow{2}{*}{$\begin{array}{c}\text { Number } \\
\text { of } \\
\text { mice }\end{array}$} & \multicolumn{6}{|c|}{$\begin{array}{l}\text { Numbers of individuals with incubation periods in SD groups } \\
\text { less than }(-) \text { or more than }(+) \text { the mean for weanlings. }\end{array}$} \\
\hline & & & & & $->3 \mathrm{SD}$ & $-2 \mathrm{~s}$ to & $\begin{aligned}-2 & \text { to } \\
+ & S D\end{aligned}$ & $\begin{aligned} & +2 \text { to } \\
+ & 3 \mathrm{SD}\end{aligned}$ & $+>3 \mathrm{SD}$ & Survivors $\dagger$ \\
\hline $22 \mathrm{~A}$ & VM & $10^{-2}$ & $\begin{array}{c}21-28 \\
4-6 \\
1 \\
0\end{array}$ & $\begin{array}{r}27 \\
16 \\
8 \\
10\end{array}$ & $\begin{array}{l}0 \\
2 \\
0 \\
1\end{array}$ & $\begin{array}{l}2 \\
0 \\
0 \\
0\end{array}$ & $\begin{array}{r}24 \\
9 \\
0 \\
0\end{array}$ & $\begin{array}{l}1 \\
1 \\
0 \\
0\end{array}$ & $\begin{array}{l}0 \\
1 \\
0 \\
0\end{array}$ & $\begin{array}{l}0 \\
3 \\
8 \\
9\end{array}$ \\
\hline $79 \mathrm{~A}$ & VL & $10^{-2}$ & $\begin{array}{c}20-28 \\
6-7 \\
2-3 \\
0-1\end{array}$ & $\begin{array}{l}37 \\
28 \\
15 \\
24\end{array}$ & $\begin{array}{l}0 \\
0 \\
0 \\
1\end{array}$ & $\begin{array}{l}1 \\
6 \\
0 \\
1\end{array}$ & $\begin{array}{r}34 \\
15 \\
5 \\
0\end{array}$ & $\begin{array}{l}2 \\
5 \\
6 \\
2\end{array}$ & $\begin{array}{r}0 \\
2 \\
4 \\
11\end{array}$ & $\begin{array}{l}0 \\
0 \\
0 \\
9\end{array}$ \\
\hline ME7 & C57BL & $\begin{array}{l}10^{-1} \\
10^{-2}\end{array}$ & $\begin{array}{c}21-28 \\
7-8 \\
0 \\
21-28 \\
4-8 \\
2 \\
0-1 \\
21-28 \\
8 \\
3 \\
0\end{array}$ & $\begin{array}{r}8 \\
6 \\
17 \\
20 \\
31 \\
7 \\
31 \\
11 \\
8 \\
5 \\
6\end{array}$ & $\begin{array}{l}0 \\
2 \\
7 \\
0 \\
3 \\
1 \\
0 \\
0 \\
0 \\
0 \\
1\end{array}$ & $\begin{array}{l}1 \\
0 \\
3 \\
0 \\
4 \\
3 \\
4 \\
0 \\
0 \\
0 \\
0\end{array}$ & $\begin{array}{r}7 \\
4 \\
2 \\
19 \\
10 \\
2 \\
18 \\
10 \\
2 \\
0 \\
0\end{array}$ & $\begin{array}{l}0 \\
0 \\
0 \\
1 \\
5 \\
1 \\
1 \\
1 \\
1 \\
0 \\
1\end{array}$ & $\begin{array}{l}0 \\
0 \\
5 \\
0 \\
9 \\
0 \\
8 \\
0 \\
5 \\
5 \\
2\end{array}$ & $\begin{array}{l}0 \\
0 \\
0 \\
0 \\
0 \\
0 \\
0 \\
0 \\
0 \\
0 \\
2\end{array}$ \\
\hline
\end{tabular}

* The individual incubation periods are classificd in terms of standard deviations (SD) from the mean incubation period in weanling mice.

$\uparrow$ Mice more than 550 days old, died or killed, with no signs of scrapie. 
tentative conclusion that newborn mice lack one or more relevant sets of receptor cells, raises three possibilities for the fate of the agent. It could be removed either by excretion (for example, the neonatal gut is permeable at least to proteins), or by sequestration in tissues where it cannot replicate, do damage or gain access to target cells, or it could be inactivated enzymically, possibly by macrophages. Cases with very short incubation, in contrast, could result from high doses of agent overloading the hypothetical disposal systems, thus leaving some agent available when the receptors mature. This could be earlier in some individuals than others.

These experiments may explain maternal transmissions in sheep ${ }^{17}$ and its absence in mice ${ }^{18}$, because sheep are born with relatively more mature lymphoreticular responses ${ }^{19}$. This implies that the postulated receptors, though absent in newborn mice, are present in the sheep foetus.

We thank Mrs I. McConnell for assistance and the Association of Scottish Branches of the Multiple Sclerosis Society for financial help.

\section{G. W. OUTraM \\ A. G. DICKINSON \\ H. FRASER}

$A R C$ Animal Breeding Research Organization,

Edinburgh EH9 $3 J Q$, and

Moredun Research Institute,

Edinburgh $\mathrm{EH} 17 \mathrm{7JH}$

Received September 21; revised October 12, 1972.

${ }^{1}$ Kimberlin, R. H., and Millson, G. C., Lancet, i, 444 (1972).

2 Dickinson, A. G., and Meikle, V. M. H., Molec. Gen. Genet., 112 , 73 (1971).

${ }^{3}$ Dickinson, A. G., and Meikle, V. M. H., Genet. Res., 13, 213 (1969).

${ }^{4}$ Dickinson, A. G., Meike, V. M. H., and Fraser, H., J. Comp. Pathol., 78, 293 (1968).

5 Fraser, H., and Dickinson, A. G., J. Comp. Pathol., 78, 301 (1968).

${ }^{6}$ Fraser, H., and Dickinson, A. G., J. Comp. Pathol. (in the press).

7 Eklund, C. M., Kennedy, R. C., and Hadlow, W. J., J. Infect. Dis., 117, 15 (1967).

${ }^{8}$ Argyris, B. F., J. Exp. Med., 128, 459 (1968).

9 Tyan, M. L., J. Immunol., 100, 535 (1968).

10 Johnson, R. T., J. Exp. Med., 120, 359 (1964).

11 Hirsch, M. S., Zisman, B., and Allison, A. C., J. Immunol., 104, $1160(1970)$

12 Clarke, M. C., and Haig, D. A., Vet. Rec., 78, 647 (1966).

13 Gardiner, A. C., and Marucci, A. A., J. Comp. Pathol., 72, 233 (1969).

14 Gresser, I., and Pattison, I. H., J. Gen. Virol., 3, 295 (1968).

15 Katz, M., and Koprowski, H., Nature, 219, 639 (1968).

16 Field, E., J., Joyce, G., and Keith, A., J. Gen. Virol., 5, 149 (1969).

17 Dickinson, A. G., Lancet, i, 1166 (1967).

18 Clarke, M. C., and Haig, D. A., Brit. Vet. J., 127, 32 (1971).

19 Schinckel, P. G., and Ferguson, K. A., Aust. J. Biol. Sci., 6, 533 (1953).

\section{In vitro Morphine Antagonism by Antibodies}

MORPHINE has a variety of pharmacological effects including inhibition of motility of some types of smooth muscle $e^{1,2}$. The narcotic antagonists nalorphine and naloxone appear to reverse a majority of the pharmacological effects of morphine by competitive inhibition for the tissue receptor site $^{1,2}$. Our study was designed to determine if antibodies reactive with morphine could also inhibit or successfully reverse one of the biologic actions of the drug. We examined the capacity of rabbit antibodies produced by immunization with 6-succinyl-morphine conjugated to bovine serum albumin (M-6-HS-BSA $)^{3,4}$ to antagonize the depressant action of morphine on electrically-induced contractions of isolated guinea pig ileum.

A concentrated crude globulin fraction of hyperimmune serum obtained from a rabbit immunized with M-6-HS-BSA

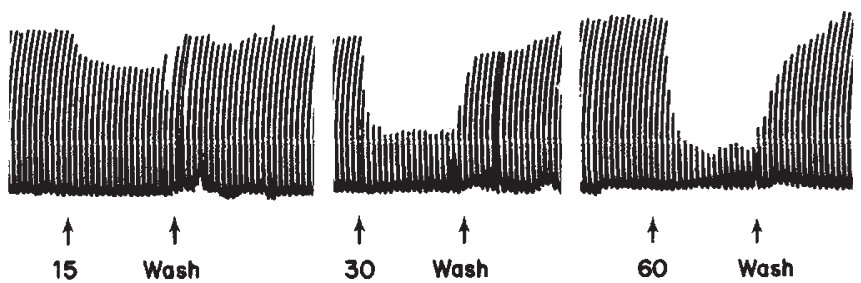

Fig. 1 Effect of $15 \mathrm{nM}, 30 \mathrm{nM}$, and $60 \mathrm{nM}$ morphine concentrations on the electrically-induced contractions of isolated guinea pig ileum. The amount of morphine added is expressed in terms of the final molar drug concentration in the bath that is $60 \mathrm{nM}$ represents $0.6 \mathrm{nmol}$ added to the $10 \mathrm{ml}$. bath. The drug was added to the muscle bath for 3 min periods and then washed out. There was an interval of at least $15 \mathrm{~min}$ between the addition of different drug concentrations.

was prepared by precipitation with $50 \%$ ammonium sulfate followed by pressure dialysis. The reactivity of the antiserum has been studied in detail ${ }^{5}$. Concentrations of various opioids inhibiting binding of $88 \mathrm{pmol} \mathrm{ml}^{-1}$ of ${ }^{14} \mathrm{C}$-morphine by $50 \%$ were ; heroin, $0.10 \mathrm{nmol} \mathrm{ml}^{-1}$;

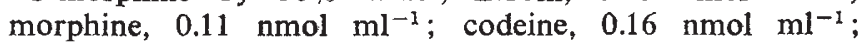
hydromorphine, $0.50 \mathrm{nmol} \mathrm{ml}^{-1}$; nalorphine, $2.1 \mathrm{nmol} \mathrm{ml}^{-1}$; meperidine, $80 \mathrm{nmol} \mathrm{ml}^{-1}$; and naloxone, $30 \%$ inhibition at $1 \times 10^{3} \mathrm{nmol} \mathrm{ml} \mathrm{m}^{-1}$. The concentrated globulin fraction bound 91,000 pmol morphine $\mathrm{ml}^{-1}$ as determined by the ammonium sulfate method ${ }^{6,7}$ when the concentration of added antigen was $88 \mathrm{pmol} \mathrm{ml} \mathrm{m}^{-1}{ }^{14} \mathrm{C}$-morphine. Crude globulin from normal rabbit serum (NRS) and from rabbit antiserum reactive with BSA (anti-BSA) were prepared and concentrated by the same procedures. Specific binding of ${ }^{14} \mathrm{C}$-morphine was not detected in either serum before or after ammonium sulfate fractionation. The protein concentration of each crude globulin fraction was adjusted to $30 \mathrm{mg} \mathrm{ml}^{-1}$.

The assay for morphine activity was based on the depressant action of morphine on the electrically stimulated contractions of the longitudinal muscle of guinea pig ileum $^{8,9}$. The ileal segment was stimulated coaxially with 1.5 times maximal rectangular pulses of $0.8 \mathrm{msec}$ duration at a frequency of 6 pulses $\min ^{-1}$, and the muscle twitch was measured isometrically with an "E\&M Model Six physiograph" and "Type A pressure transducer". There was an interval of at least $15 \mathrm{~min}$ between additions of different drug mixtures to the bath.

The inhibitory effect of increasing concentrations of morphine hydrochloride on the muscle twitch is shown in Fig. 1. The drug was allowed to remain in the bath for 3 min and then washed out. Inhibition was observed immediately upon addition of morphine to the bath and this inhibition was reversed on removal of the drug by washing. The lowest concentration at which this effect could be detected was at $15 \mathrm{nM}$ morphine. Inhibition was $70-80 \%$ complete at $60 \mathrm{nM}$ morphine concentration.

The capacity of anti-M-6-HS-BSA to antagonize the depressent actions of morphine on the ileal segments was measured. Varying concentrations of morphine were preincubated with $0.4 \mathrm{ml}$. of antibody globulin for $15 \mathrm{~min}$ at room temperature, and then added to the tissue bath for 3 min. This amount of antibody inhibited the effect of morphine concentrations ranging from $60 \mathrm{nM}$ to $1,000 \mathrm{nM}$ (Fig. 2). Morphine preincubated with NRS globulin retained full activity, and addition of antibody or NRS globulin alone had no effect on the contractility of the ileal muscle. This prevention of the pharmacological effect of morphine on isolated guinea pig ileum was probably due to the morphineantibody combination stopping the morphine reaching the biological receptor sites. Prevention of the morphine effect was complete when a two-fold stoichiometric excess of antibodies was present.

To determine if antibody was able to reverse morphine 